\begin{tabular}{l|c|c}
\hline ISSN: 0001-5113 & ACTA ADRIAT., & ORIGINAL SCIENTIFIC PAPER \\
AADRAY & $62(2): 159-170,2021$ & \\
\hline
\end{tabular}

\title{
Body morphometric and otolith shape analyses of anchovy (Engraulis encrasicolus (Linnaeus, 1758)) in the Algerian basin
}

\author{
Khadra FERHANI ${ }^{1,2, *}$, Djamel BEKRATTOU ${ }^{1}$ and Salim MOUFFOK ${ }^{1}$ \\ ${ }^{1}$ LRSE/Department of Biology, Faculty of Natural Sciences and Life, University of Oran 1, \\ Ahmed BENBELLA, Oran, Algeria \\ ${ }^{2}$ National Center for Research and Development of Fisheries and Aquaculture (CNRDPA), \\ Bou-Ismail, Tipaza, Algeria \\ *Corresponding author: k.ferhani@cnrdpa.dz
}

\begin{abstract}
Body morphometric characteristics and otolith shape described by elliptic Fourier descriptors analyses were carried out on European anchovy (Engraulis encrasicolus) samples collected from six locations in Algerian waters during the acoustic survey ALPEL2018 (south-western Mediterranean Sea, GFCM-GSA04). The discriminant analysis was applied over twelve morphometric body distances and 31 normalized elliptic Fourier descriptors. It highlighted significant difference between areas but with high overlapping. No significant difference was detected between males and females, or right and left otoliths. Hierarchical clustering analysis conducted on the mean form of body and otolith shape showed a clear geographical cline. The results indicate that the geographical trend is present with a high level of overlapping between the near areas, suggesting that European anchovies in Algerian waters are not completely isolated.
\end{abstract}

Key words: Morphometric characteristics; otolith shape; anchovy; Algeria

\section{INTRODUCTION}

The European anchovy, Engraulis encrasicolus (Linnaeus, 1758), a clupeoid fish, is distributed along the eastern Atlantic coast from Scandinavia to west Africa and is also found in the Mediterranean, Black and Azov Seas (WHITEHEAD, 1985). This commercially important species is usually consumed more salty than fresh in Algeria. Stocks of this small pelagic fish are very sensitive to variations in their ecosystem, which makes their management for conservation difficult and requires good knowledge of stock structure. Fish populations can be grouped under various characteristics: geographical areas including environmental conditions, spawning grounds, feeding areas and migrations. All of these characteristics can recognize a population structure in a fish species. However, fisheries management, which is generally based on stock units (basic concept), performs adequately when the stock structure is known.

Fish stock discrimination has been measured using several different methods. BEGG \& WALDMAN (1999) and IHSSEN et al. (1981) analysed different approaches to stock identification, and recommended a holistic approach because the 


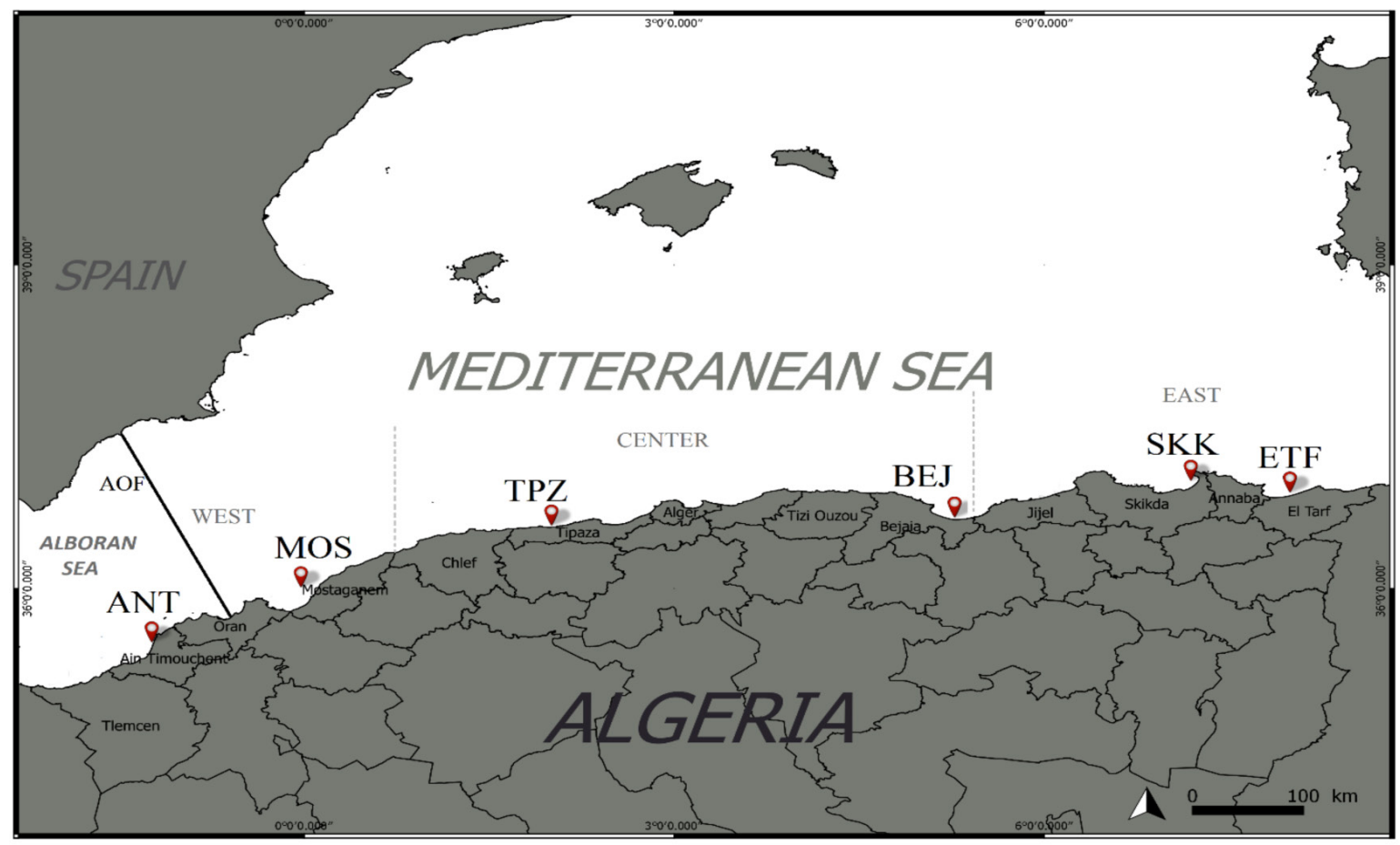

Fig. 1. Sampling locations of European anchovy, administrative subdivisions of Algerian coast (West, Center and East) and position of the Almeria-Oran front (AOF)

integration of the results of each method used provides information at the spatial (from local to regional) and temporal (from daily to evolutionary) scales. This work examines the population structure of anchovy inhabiting the Algerian coasts based on variations in otolith shape and body morphometric characteristics. The study of morphological characteristics to identify or characterize the population has a long tradition in ichthyology and has been used successfully for stock identification (CLAUDE, 2008). Morphometric characteristics are continuous characteristics describing aspects of shape. The European anchovy (Engraulis encrasicolus) has been the subject of several body morphological studies (JUNQUERA \& PEREZ-GANDARAS, 1993; TUDELA, 1999; TURAN et al., 2004; TRAINA et al., 2011; BAŞÇINAR, 2020).

Fish otoliths are an indirect means of studying fish populations and assessing the relationship between the environment and organisms (LORD et al., 2012). Otolith shape analysis using elliptic Fourier descriptors represents a precise and powerful method for describing and characterizing outlines (KUHL \& GIARDINA, 1982). This approach has been used in stock discrimination studies of European anchovy by many scientists in the Mediterranean Sea, especially in the northern region (MESSAOUD et al., 2011; JEMAA, 2014; KARAHAN et al., 2014; BACHA et al., 2014; ZENGIN et al., 2015; BAŞÇINAR \& ATILGAN, 2016; KHEMIRI et al., 2018; AKKUS et al., 2018; ERDOĞAN et al., 2019). Furthermore, studies on the structure of anchovy are abundant on the northern shore of the Mediterranean Sea than the southern shore, and not by a single approach but by others such as allozyme (ERDOĞAN et al., 2009) and genetic (BEMBO et al., 1996; MAGOULAS et al., 1996; BOUCHENAK-KHELLADI et al., 2008; VINÃS et al., 2014; KARAHAN et al., 2014) analyses.

The present study aims to investigate the stock structure of the European anchovy E. encrasicolus based on body morphometric characteristics and otolith shape throughout the Algerian coast in the south-western Mediterranean Sea, to understand the stock structure of this small pelagic species for fisheries management. 


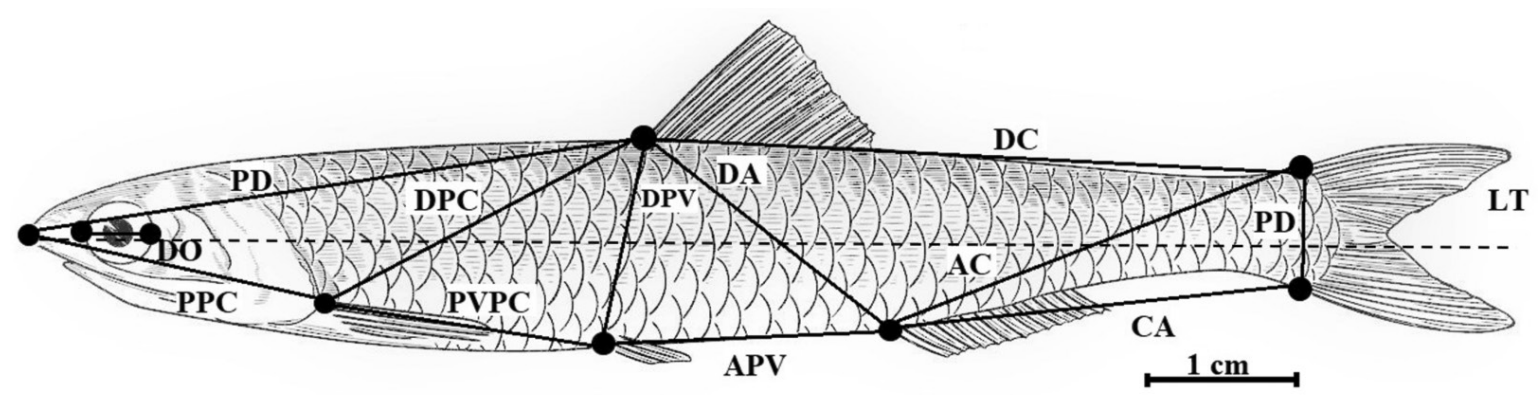

Fig. 2. Measurements taken on Engraulis encrasicolus (PD: distance from the end of the muzzle to the beginning of the dorsal fin; DC: distance from the beginning of the dorsal fin to beginning of the caudal fin; PC: between the two insertions of the caudal fin; $C A$ : from the caudal fin to the beginning of the anal fin; APV: distance from the beginning of the anal fin to beginning of the pelvic fin; PVPC: distance from the beginning of the pelvic fin to beginning of the pectoral fin; PPC: from the beginning of the pectoral fin to the tip of the mouth; DPC: distance from the beginning of the dorsal fin to beginning of the pectoral fin, DPV: distance from the beginning of the dorsal fin to beginning of the pelvic fin; $D A$ : distance from the beginning of the dorsal fin to beginning of the anal fin; AC: distance from the beginning of the anal fin to beginning of the caudal fin; DO: eye diameter; LT: total length)

\section{MATERIAL AND METHODS}

\section{Study area and sampling}

Samples of European anchovy were collected at six locations in Algerian territorial waters in the southwestern Mediterranean Sea between $35^{\circ} 05^{\prime} \mathrm{N}-02^{\circ} 12^{\prime} \mathrm{W}$ and $36^{\circ} 56^{\prime} \mathrm{N}-08^{\circ} 38^{\prime} \mathrm{E}$ (Fig. 1). The samples were caught with a pelagic trawl during the annual acoustic survey ALPEL (ALgerian PELagic) conducted between December 2018 and January 2019 with the research vessel Belkacem Grine. Sea surface temperature and salinity were measured continuously using a thermosalinograph (Model SBE 21), and the salinity-temperature profile was determined by a CTD (Model SBE 25).

Sampling was conducted during the same season to avoid a seasonal effect on the results if it exists. A total of 407 specimens were col- lected. Table 1 lists the sampling locations and some biological aspects of the samples. The left side of each fresh fish was photographed with a ruler to obtain scale information using a digital camera, then individually placed in plastic bags and kept frozen $\left(-20^{\circ} \mathrm{C}\right)$ until transportation to the laboratory. Otolith extraction and sex determination were carried out in the laboratory. The number of individuals used in each analysis was different, as damaged individuals and broken otoliths were discarded.

\section{Body morphometric}

During the analysis, 12 morphometric distances were measured (Fig. 2). The network selection of morphometric variables was made according to the criteria of being easily repeatable from one shape to another. The measurements were obtained after image treatment using image processing software.

Table 1. Summarized information on sampling locations and European anchovy samples from the Algerian basin

\begin{tabular}{l|cccccccccc}
\hline $\begin{array}{l}\text { Sampling } \\
\text { Area }\end{array}$ & $\begin{array}{c}\text { Code } \\
\text { Area }\end{array}$ & Date & Depth & $\begin{array}{c}\text { Surf } \\
\boldsymbol{T}^{\circ} \boldsymbol{c}\end{array}$ & $\begin{array}{c}\text { Surf } \\
\boldsymbol{S \% o}^{*}\end{array}$ & $\begin{array}{c}\text { Depth } \\
\boldsymbol{T}^{\circ} \boldsymbol{c}\end{array}$ & $\begin{array}{c}\text { Depth } \\
\text { S\%o }\end{array}$ & $\begin{array}{c}\text { Sample } \\
\text { size }\end{array}$ & $\begin{array}{c}\text { Range of TL } \\
(\mathbf{c m})\end{array}$ & $\begin{array}{c}\text { Mean TL } \\
(\mathbf{c m})\end{array}$ \\
\hline $\begin{array}{l}\text { Ain } \\
\text { Temouchent }\end{array}$ & ANT & $20 / 12 / 2018$ & 69.02 & 16.87 & 36.59 & 16.47 & 36.96 & 60 & $7.4-15.6$ & $12.5 \pm 0.18$ \\
Mostaganem & MOS & $24 / 12 / 2018$ & 69.5 & 16.63 & 36.46 & 16.26 & 37.29 & 69 & $7.6-15.1$ & $11.2 \pm 0.25$ \\
Tipaza & TPZ & $26 / 12 / 2018$ & 41 & 16.83 & 36.57 & 16.63 & 36.62 & 76 & $11.1-17.8$ & $12.6 \pm 0.13$ \\
Bejaia & BEJ & $17 / 01 / 2019$ & 40 & 15.64 & 36.78 & 15.58 & 36.87 & 60 & $9.6-13.5$ & $11.5 \pm 0.19$ \\
Skikda & SKK & $20 / 01 / 2019$ & 55.8 & 14.60 & 36.47 & 15.82 & 36.91 & 82 & $7.9-14.4$ & $11.9 \pm 0.17$ \\
El Tarf & ETF & $21 / 01 / 2019$ & 37 & 15.34 & 36.84 & 15.75 & 36.93 & 60 & $8.4-14.5$ & $9.9 \pm 0.25$ \\
\hline
\end{tabular}


All measured characteristics were recalculated and standardized to eliminate body size effect following the method of THORPE (1975) and LLEONART et al. (2000) for each fish as follows:

$$
\overline{\mathrm{Y}}_{i}=\mathrm{Y}_{i}\left(\mathrm{X}_{0} / \mathrm{X}_{i}\right)^{b}
$$

where, $\bar{Y}_{i}$ is the size-adjusted measurement, $\mathrm{Y}_{i}$ is the original morphometric measurement, $\mathrm{X}_{0}$ is

the mean of total length for all fish from all samples, $\mathrm{X}_{i}$ is the total length of fish and the parameter $b$ is the slope of the regression of $\log \mathrm{Y}_{i}$ and $\log \mathrm{X}_{i}$ using all specimens.

The morphometric data were first analysed by a multivariate analysis of variance (MANOVA) to test the significance between sexes and areas for the statistical analyses. In addition, standardized measurements were submitted to linear discriminant analysis (LDA), useful for predicting groups. The objective of this analysis was to group the examined fishes into homogenous groups according to their body morphometric characteristics. The performance of the discriminant analysis was evaluated by the Wilk's lambda test. Finally, a hierarchical clustering analysis was conducted on the mean of the morphometric distances using Ward' s hierarchical algorithm based on Euclidean distances.

\section{Otolith Shape}

Subsequently, 392 sagittal otoliths (left and right) were photographed under reflected light using a camera connected to an Optika loupe. The otoliths were positioned with the sulcus acusticus facing downwards and the rostrum to the left. Only the right otolith was used in this analysis, however, when the right sagittae was damaged, the images of the left otolith were rotated to a standard position using mirror image software. Thus, 99 normalized elliptic Fourier descriptors (NEFDs) or harmonics were extracted using the TNPC software (Digital processing for calcified structures, version 7.1) (Fig. 3). Each harmonic was described by four Fourier coefficients, a Fourier power test was calculated and $99.99 \%$ of the accumulated variance was adopted to determine the minimum number of harmonics required to reconstruct the otolith contour (CRAMPTON, 1995). The coefficients A, $\mathrm{B}, \mathrm{C}$, and $\mathrm{D}$ derived from the first harmonic were not considered because they formed an ellipse without contour information.

For the data analysis, principal component analysis (PCA) was applied to summarize the information contained in the coefficients and reduce the number of variables according to the broken stick model (ALMORZA \& HORTENSIAGARCÍA, 2008). Next, the influence of sex, side and area were tested using redundancy analysis (RDA) combined with permutation tests. Again, LDA was applied. Finally, hierarchical clustering analysis according to Ward' $\mathrm{s}$ hierarchical algorithm based on Euclidean distances was performed on the averages of the normalized Fourier descriptors (NEFDs).

All statistical analyses were performed using the statistical environment $\mathrm{R}$ version 3.6.1 (R Development Core Team, http://www.R-project.org) with the following packages installed: MASS (RIPLEY et al., 2013), ade4 (DRAY \& DUFOUR, 2007), vegan (OKSANEN et al., 2013) and ggplot2 (WICKHAM, 2016).

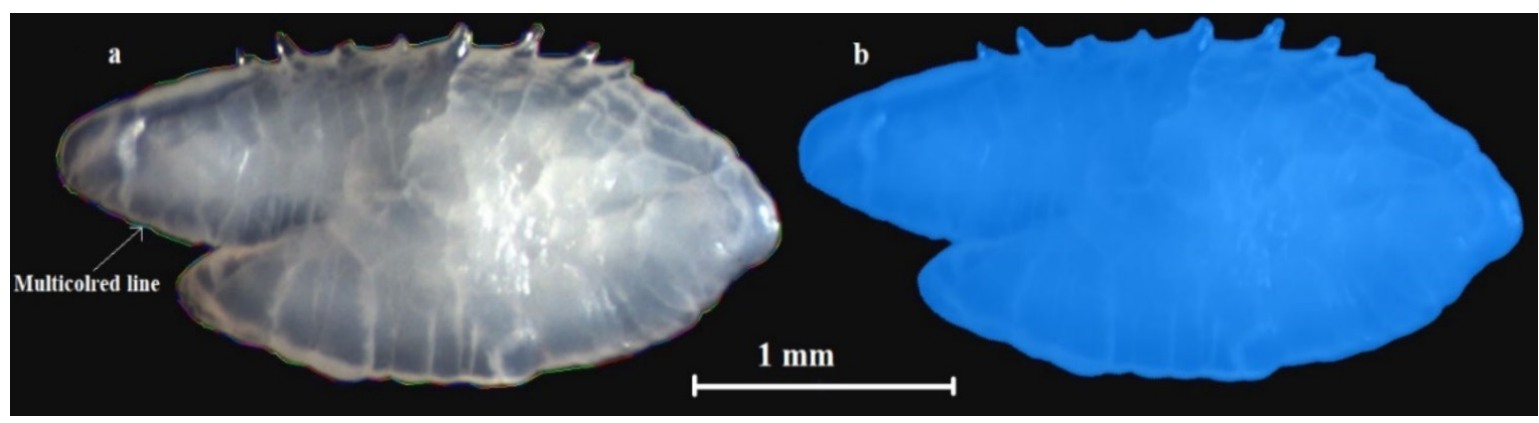

Fig. 3. Images of right sagitta from European anchovy (E. encrasicolus), a: otolith with the multicolored line representing the contour, b: binarized image of the otolith produced with TNPC 


\section{RESULTS}

\section{Body morphometric}

The results of the multivariate analysis of variance (MANOVA) applied to study the significance of sex factor on body morphometric variables show no sexual dimorphism in any of the samples (Wilks' $\lambda=0.97, P>0.05$ ). However, the results reveal significant differences between the six areas samples (Wilks' $\lambda=0.27$, $P<0.05)$. The first two discriminant functions, represent $85 \%$ of the total variance (Fig. 4). The LDA performed with these data revealed an unclear separation of anchovies on the Algerian coasts. The first function seemed to separate Ain Temouchent and Mostaganem from the other areas according to morphometric characteristics. Two main groups can be distinguished: the first group included samples from the western and central areas, except for Ain Temouchent, the second group included the sample from the eastern area (Bejaia, Skikda and El Tarf) and the west coasts (Ain Temouchent) (Fig. 4).

The overall assignment of individuals in their original sample by LDA is $53.6 \%$ (Table 2 ), ranging from a high of $80 \%$ (Tipaza) to a low of $40 \%$ (Ain Temouchent). The proportion of individuals correctly classified in their initial samples reveals an intermingling between the samples of Bejaia (50\%), Skikda (46\%), and El Tarf (43\%). The results of the hierarchical clustering analysis performed on the means of morphometric characteristics indicate that Bejaia, Skikda, and El Tarf are grouped in the same

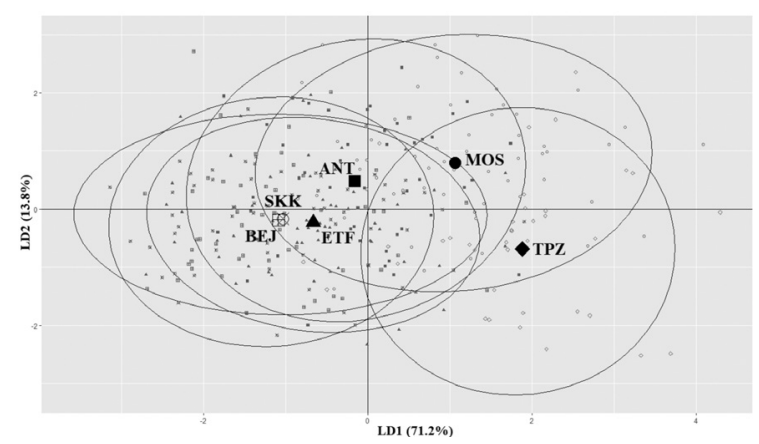

Fig. 4. Discriminant analysis plot with $95 \%$ confidence ellipses for morphometric analysis of E. encrasicolus

cluster and Ain Temouchent with Mostaganem. Tipaza samples are distinguished from the other samples (Fig. 5). The results (except Tipaza) were related to geographical location.

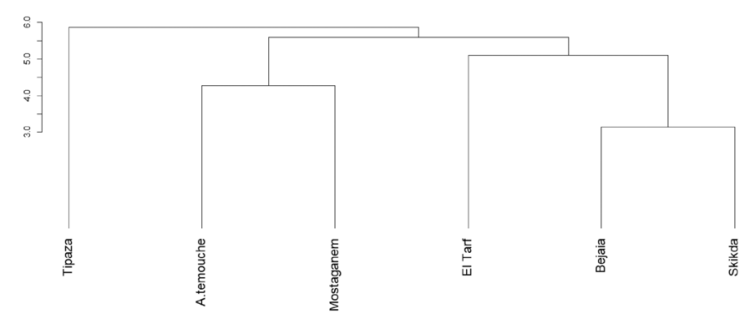

Fig. 5. Hierarchical clustering analysis conducted on centroids of body morphometric distances of $\mathrm{E}$. encrasicolus

\section{Otolith shape}

The results of the Fourier analysis indicate that the otolith shape of anchovy can be summarized by 31 harmonics that reached a value equal to $99.99 \%$ of the average cumulative percentage of Fourier Power. Thus, 124 Fourier coefficients were used for data analysis. Redundancy

Table 2. Percentage of individuals of European anchovy reclassified in each group in the linear discriminant analysis based on body morphometry

\begin{tabular}{|c|c|c|c|c|c|c|}
\hline & \multicolumn{7}{|c|}{ Original group } \\
\hline $\begin{array}{c}\text { Re-allocation } \\
\text { group }\end{array}$ & ANT & MOS & TPZ & BEJ & SKK & ETF \\
\hline ANT & $\mathbf{4 0}$ & 20 & 1.7 & 18.3 & 10 & 10 \\
\hline MOS & 10 & $\mathbf{6 1 . 7}$ & 15 & 5 & 1.7 & 6.7 \\
\hline TPZ & 1.7 & 10 & $\mathbf{8 0}$ & 5 & 1.7 & 1.7 \\
\hline BEJ & 15 & 1.7 & 1.7 & $\mathbf{5 0}$ & 15 & 16.7 \\
\hline SKK & 8.3 & 5 & 5 & 18.3 & $\mathbf{4 6 . 7}$ & 16.7 \\
\hline ETF & 15 & 1.7 & 6.7 & 8.3 & 25 & $\mathbf{4 3 . 3}$ \\
\hline
\end{tabular}


Table 3. Percentage of individuals of European anchovy reclassified in each group by LDA based on otolith shape

\begin{tabular}{|c|c|c|c|c|c|c|}
\hline & \multicolumn{7}{|c|}{ Original group } \\
\hline $\begin{array}{c}\text { Re-allocation } \\
\text { group }\end{array}$ & ANT & MOS & TPZ & BEJ & SKK & ETF \\
\hline ANT & $\mathbf{1 2}$ & 25 & 30 & 2 & 18 & 14 \\
\hline MOS & 7 & $\mathbf{4 5}$ & 25 & 0 & 16 & 7 \\
\hline TPZ & 9 & 20 & $\mathbf{3 8}$ & 0 & 26 & 7 \\
\hline BEJ & 6 & 16 & 35 & $\mathbf{4}$ & 31 & 8 \\
\hline SKK & 9 & 15 & 16 & 1 & $\mathbf{4 8}$ & 12 \\
\hline ETF & 2 & 4 & 5 & 0 & 28 & $\mathbf{6 1}$ \\
\hline
\end{tabular}

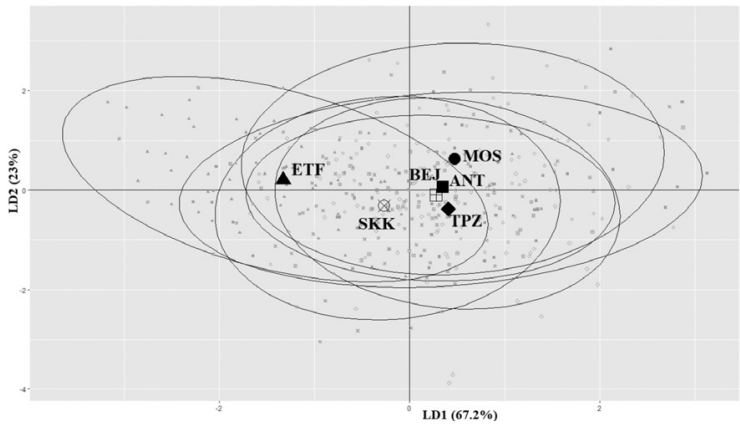

Fig. 6. Discriminant analysis plot with $95 \%$ confidence ellipses for otolith shape analysis of European anchovy (E. encrasicolus)

analysis (RDA) combined with permutation tests of both otoliths show no significant difference between right and left otoliths $(P>0.05)$, between males and females. For this purpose, as the left and right otoliths of anchovy were comparable, 285 right otoliths and 107 left otoliths were combined in this study. However, a significant difference can be observed between areas $(P<0.05)$. The first five PCs are significant, as determined by the broken-stick model; they explained $82.2 \%$ of the total variance.

The result of the LDA conducted to discriminate anchovy between areas shows a low correct classification rate of $36.4 \%$, indicating that the majority of groups were not clearly differentiated (Table 3). The first analysis of discriminant functions explains $67.2 \%$ of the total variance and the second $23 \%$. The combined explained variance across axes 1 and 2 is $90.3 \%$. The LDA reveals a separation between two groups. Despite the considerable overlapping among the samples, it can be noted that the western and central samples (Ain Temouchent, Mostaganem, Tipaza, and Bejaia) are slightly segregated from

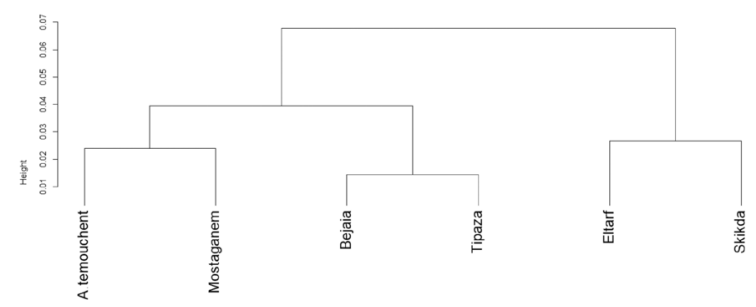

Fig. 7. Hierarchical clustering analysis on centroids of NEFDs of European anchovy (E. encrasicolus)

a group formed by the eastern samples (Skikda and El Tarf) (Fig. 6). In the second group, samples from the extreme east (El Tarf) seem to form a distinct group, with $61 \%$ of specimens correctly classified.

The hierarchical clustering analysis shows a clear geographical cline. The groupings are consistent with the location of the area from west to east of the Algerian coast (Fig. 7). In the west, Ain Temouchent is grouped with Mostaganem in the same cluster, the second is formed by central areas (Tipaza and Bejaia), and the eastern samples (Skikda and El Tarf) are clustered together.

\section{DISCUSSION}

This study aimed to study the shape whether body or otolith to structure the population. It was conducted on samples of European anchovy (Engraulis encrasicolus) caught in Algerian waters. The $95 \%$ confidence ellipses in the discriminant analysis of all samples overlapped and were not clearly distinct for the two approaches, indicating a low level of morphological heterogeneity. No significant differences in body morphometrics and otolith shape were observed between 
males and females. The LDA groups samples from Ain Temouchent, Mostaganem, Tipaza in Group 1, and Skikda and El Tarf in Group 2. However, for Bejaia, body morphometry analysis classifies the samples with the first group. With otolith shape analysis, they have an affinity with the second group. A comparison between the body and otolith shape study conducted on the Pacific sardine, Sardinops sagax by VERGARA-SOLANA et al. (2013) indicates that the otolith shape is the least variable compared to the body shape. For the hierarchical clustering analysis, the geographical trend is apparent. Whatever the approach, neighbouring areas were grouped in the same cluster.

Morphometric differences in European anchovy in the eastern Mediterranean, including the Black and Aegean Seas, are related to differences in spawning grounds (TURAN et al., 2004). The effects of some environmental factors on spawning groups may determine the potential phenotypic discreetness of the anchovy (SANZ et al., 2008). From an oceanographic perspective, the Algerian coasts are characterized by a complex circulation pattern (MILLOT \& TAUPIER-LETAGE, 2005). They belong to two basins separated by the Almeria-Oran Front: the eastern Alboran Sea and the Algerian basin (BENZOHRA \& MILLOT, 1995; PUILLAT et al., 2002). Numerous studies have suggested that the Alboran Sea population is genetically distinct from the Mediterranean population (VINAS et al., 2014; BOUCHENAK-KHELLADI et al., 2008), and suggest that the Almeria-Oran front is considered a barrier for anchovies. The same results were found by BACHA et al. (2014) using the otolith shape approach and indicated that samples from the Alboran Sea differ from other Mediterranean samples.

However, AKKUS et al. (2018) combined samples from previous otolith shape studies and identified 3 differentiated groups (north-western Mediterranean, eastern Mediterranean- Black Sea, and Atlantic- south-western Mediterranean Sea) that include our study area. Overall, the European anchovy reveals a complex population structure that has produced conflicting results in previous genetic studies (BACHA et al., 2014). Our sampling does not define the Almeria-Oran front effect, as samples from Ain Temouchent in the Alboran Sea are closer to those from neighbouring areas such as Mostaganem and Tipaza in the Algerian basin. Another interesting result was obtained by BOUCHENAK-KHELLADI et al. (2008), and it is relevant for the present work. The authors found an intermediate form using the genetic approach between E. albidus and $E$. encrasicolus, indicating a possible hybridization in eastern Algeria. For this study, the results of the LDA conducted on otolith shape indicate that the El Tarf samples are distinct from the others, considering the sampling location near the estuary and in inshore. Furthermore, the presence of the newly described species $E$. albidus cannot be excluded because although the primary habitat of this species is restricted to the lagoon, estuaries, E. albidus can live inshore in coastal marine waters (BORSA et al., 2004).

The results of the morphological studies interpret the interaction between aspects of species biology (aggregation, migration) and ecological and environmental aspects. IHSSEN et al. (1981) noted that phenotypic variability is particularly high in fish, and is not necessarily associated with high genetic variability. The total isolation, e.g., in the reproduction sense, may not necessarily be absolute. Nevertheless, assuming that morphological and ecological divergence are affected by the environment, it can be assumed that a significant fraction of each group spends its life in distinct regions. Hydrographic conditions may explain the origin and maintenance of the population structure in several species (SPANAKIS et al., 1989). However, integration of morphometric information with other approaches, such as analysis of life-history parameters, otolith chemistry, or genetic data, is essential for efficient stock identification (BEGG \& WALDMAN, 1999; CADRIN, 2014).

\section{CONCLUSIONS}

This paper investigated the population structure of anchovy distributed along the Algerian coast based on variations in otolith shape and body morphometric characteristics. The sampling results at a small geographic scale (Alge- 
rian coast) indicated that the geographic trend is present with a high level of overlapping between the near areas. Therefore, it can be suggested that European anchovy in the Algerian waters exists as semi-independent but not completely isolated. Body and otolith shape can be useful if the genetics and spawning areas are adequately understood. These approaches may provide different results, but additional information on the population structure is needed because the set of each characteristic and the associated methodology are linked to specific aspects of the stock definition.

\section{ACKNOWLEDGEMENTS}

The authors would like to express their appreciation to all participants in ALPEL 2018/2017 for collaboration in collecting samples particularly A. Bennoui et S. Bensmail.

This study was funded by the National Center for Research and Development of Fisheries and Aquaculture (CNRDPA) and the LRSE/ Department of Biology, University Oran 1.

The authors declare that they have no conflict of interest.

\section{REFERENCES}

AKKUS, G., S. JEMAA, A. CEMAL GUCU, P. MARCHAL, P. CARBONARA, M. BACHA, R. AMARA, B. ERNANDE, C. SARAUX \& K. MAHE. 2018. Understanding the Population Structure of the European Anchovy (Engraulis encrasicolus) in the Black Sea, Mediterranean Sea and Northeast Atlantic Ocean by Using Otolith Shape Analysis. In IOS2018-6th International Otolith Symposium 2018. 15-20 April Keelung, Taiwan.

ALMORZA, D. \& M. HORTENSIA GARCIA 2008. Results of exploratory data analysis in the broken stick model. J. Appl. Stat., 35(9): 979983. doi: 10.1080/02664760802187536.

BACHA, M., S. JEMAA, A. HAMITOUCHE, K. RABHI \& R. AMARA. 2014. Population structure of the European anchovy, Engraulis encrasicolus, in the SW Mediterranean Sea, and the Atlantic Ocean: evidence from otolith shape analysis. ICES J. Mar. Sci., 71(9): 2429-2435. doi:10.1093/icesjms/fsu097.

BAŞÇINAR, N.S. 2020. Morphometric analysis of anchovy (Engraulis encrasicolus) (Linnaeus, 1758)) otoliths in Georgia and Marmara Seas. Iran. J. Fish. Sci., 19(3): 1214-1223. doi: 10.22092/IJFS.2019.120596.

BAŞÇINAR, N.S. \& E. ATILGAN. 2016. Otolith Morphometry and Shape Analysis of Anchovy (Engraulis encrasicolus, L. 1758) living in Different Regions Black Sea: Ukraine and Türkiye (Rize, Samsun). Aqua. St.,
16(4): 311-320. doi: 10.17693/yunusae. v16i26717.281030.

BEGG, G.A. \& J.R. WALDMAN. 1999. A holistic approach to fish stock identification. Fish. Res., 43(1-3): 35-44. doi:10.1016/S01657836(99)00065-X.

BEMBO, D.G., G.R. CARVALHO, M. SNOW, N. CINGOLANI \& T.J. PITCHER. 1996. Stock discrimination among European anchovies, Engraulis encrasicolus, by means of PCR-amplified mitochondrial DNA analysis. Oceanogr. Lit. Rev., 12(43): 1274.

BENZOHRA, M. \& C. MILLOT. 1995. Hydrodynamics of an open sea Algerian eddy. Deep Sea Research Part I. Oceanogr. Res. Pap., 42(10): 1831-1847. doi :10.1016/09670637(95)00046-9.

BORSA, P., A. COLLET \& J.D. DURAND. 2004. Nuclear-DNA markers confirm the presence of two anchovy species in the Mediterranean. C. R. Biol., 327(12) : 1113-1123. doi:10.1016/j. crvi.2004.09.003.

BOUCHENAK-KHELLADI, Y., J.D. DURAND, A. MAGOULAS \& P. BORSA. 2008 Geographic structure of European anchovy: a nuclearDNA study. J. Sea. Res., 59(4): 269-278. doi:10.1016/j.seares.2008.03.001.

CADRIN, S.X. 2014. Morphometric landmarks. In: S.X. CADRIN, K.D. FRIEDLAND, J.R.WALDMAN (Editors). Stock Identification Methods: Applications in Fishery Sci- 
ence, 2nd edition. Elsevier, Inc. Amsterdam, Netherlands, pp. 109-128.

CLAUDE, J. 2008. Morphometrics with R. Springer Science \& Business Media.

CRAMPTON, J.S. 1995. Elliptic Fourier shape analysis of fossil bivalves: some practical considerations. Lethaia, 28(2): 179-186. doi:10.1111/j.1502-3931.1995.tb01611.x.

DRAY, S. \& A.B. DUFOUR .2007. The ade4 package: implementing the duality diagram for ecologists. J. Stat. Softw., 22(4): 1-20. doi:10.18637/jss.v022.i04.

ERDOĞAN, Z., C. TURAN \& T.H. KOÇ .2009. Morphologic and allozyme analyses of European anchovy (Engraulis encrasicolus (L. 1758)) in the Black, Marmara and Aegean Seas. Acta Adriat., 50(1): 77- 90.

ERDOĞAN, Z., H. KOÇ \& C. TURAN. 2019. Otolith Shape Analysis of Anchovy (Engraulis encrasicolus) in the Black, Marmara and Aegean seas. Natural and Engineering Sciences, SUPPLEMENT I of SYMPOSIUM ARTICLES, 4(3): 10-17.

IHSSEN, P.E., H.E. BOOKE, J.M. CASSELMAN, J.M. MCGLADE, N.R. PAYNE \& F.M. UTTER. 1981. Stock identification: materials and methods. Can. J. Fish. Aquat. Sci., 38(12): 1838-1855. doi:10.1139/f81-230.

JEMAA, S. 2014. Étude de la structure des populations et du régime alimentaire de l'anchois européen (Engraulis encrasicolus) et de la sardine européenne (Sardina pilchardus): relations avec l'environnement. Thesis, Université du Littoral d'Opale, France, 241 pp.

JUNQUERA, S. \& G. PEREZ-GÁNDARAS. 1993. Population diversity in Bay of Biscay anchovy (Engraulis encrasicolus L.1758) as revealed by multivariate analysis of morphometric and meristic characteristics. ICES J. Mar. Sci., 50 : 383-391. doi: 10.1006/jmsc.1993.1043.

KARAHAN, A., P. BORSA, A.C. GUCU, I. KANDEMIR, E. OZKAN, OREK YAK, Y.A. OREK, S. CAN ACAN, E. KOBAN \& I. TOGAN. 2014. Geometric morphometrics, Fourier analysis of otolith shape, and nuclear-DNA markers distinguish two anchovy species (Engraulis spp.) in the Eastern Mediterranean Sea. Fish. Res., 159: 4555. doi: 10.1016/j.fishres.2014.05.009.
KHEMIRI, S., A. GAAMOUR, L. BEN ABDALLAH \& S. FEZZANI. 2018. The use of otolith shape to determine stock structure of Engraulis encrasicolus along the Tunisian coast. Hydrobiologia, 821(1): 73-82. doi: 10.1007/s10750017-3305-1.

KUHL, F.P. \& C.R. GIARDINA. 1982. Elliptic Fourier features of a closed contour. Comput. Gr. Image Process., 18(3): 236-258. doi:10.1016/0146-664X (82)90034-X.

LLEONART, J., J. SALAT \& G.J. TORRES. 2000. Removing allometric effects of body size in morphological analysis. J. Theor. Biol., 205: 85-93. doi:10.1006/jtbi.2000.2043

LORD, C., F. MORAT, R. LECOMTE-FINIGER \& P. KEITH. 2012. Otolith shape analysis for three Sicyopterus (Teleostei: Gobioidei: Sicydiinae) species from New Caledonia and Vanuatu. Environ. Biol. Fishes, 93: 209-222. doi:10.1007/s10641-011-9907-y.

MAGOULAS, A., N. TSIMENIDES \& E. ZOUROS. 1996. Mitochondrial DNA phylogeny and the reconstruction of the population history of a species: the case of the European anchovy (Engraulis encrasicolus). Mol. Biol. Evol.,13(1):178-190. doi: 10.1093/ oxfordjournals.molbev. a025554.

MESSAOUD, H., N. BOURIGA, M.N. DALY YAHIA, M. BOUMAIZA, E. FAURE, J.P. QUIGNARD \& M. TRABELSI. 2011. Discrimination de trois populations d'anchois du genre Engraulis (Clupeiforme, Engraulidae) des côtes Tunisiennes par analyse de forme des otolithes. Bulletin of Institute of National Science Technology Mer Salammbô, 38: 21-27.

MILLOT, C. \& I. TAUPIER-LETAGE. 2005. Circulation in the Mediterranean Sea. In: A. SALIOT (Editor). The Mediterranean Sea. Handbook of Environmental Chemistry, vol 5K, Springer, Berlin, Heidelberg, pp.29-66. doi: 10.1007/b107143.

OKSANEN, J., F.G. BLANCHET, R. KINDT, P. LEGENDRE, P.R. MINCHIN, R.B. O'HARA, ...\& M. J. OKSANEN. 2013. Package « vegan ». Community ecology package, 2(9): 1-295.

PUILLAT, I., I. TAUPIER-LETAGE \& C. MILLOT. 2002. Algerian eddies lifetime can near 3 years. J. Mar. Syst., 31(4): 245-259. doi:10.1016/ S0924-7963(01)00056-2. 
RIPLEY, B., B. VENABLES, D.M. BATES, K. HORNIK, A. GEBHARDT, D. FIRTH \& M.B. RIPLEY. 2013. Package "mass". Cran R, 538:113-120.

SANZ, N., J.L. GARCÍA-MARÍN, J. VINAS, M. ROLDÁN \& C. PLA. 2008. Spawning groups of European anchovies: population structure and management implications. ICES J. Mar. Sci., 65(9):1635-1644. doi: 10.1093/icesjms/ fsn 128 .

SPANAKIS, E., N. TSIMENIDES \& E. ZOUROS. 1989. Genetic differences between populations of sardine, Sardina pilchardus, and anchovy, Engraulis encrasicolus, in the Aegean and Ionian seas. J. Fish Biol., 35(3): 417-437. doi: 10.1111/j.1095-8649. 1989.tb02993.x.

THORPE, R.S. 1975. Quantitative handling of characteristics useful in snake systematics with particular reference to intraspecific variation in the ringed snake Natrix natrix (L.). Biol. J. Linn. Soc., 7(1): 27-43. doi: 10.1111/j.10958312.1975.tb00732.x.

TRAINA, A., G. BASILONE, F. SABORIDO-REY, R. FERRERI, E. QUINCI, T. MASULLO,

S. ARONICA \& S. MAZZOLA. 2011. Assessing population structure of European Anchovy (Engraulis encrasicolus) in the Central Mediterranean by means of traditional morphometry. Adv. Oceanogr. Limnol., 2(2): 141-153. doi: 10.1080/19475721.2011.592401.

TUDELA, S. 1999. Morphological variability in a Mediterranean, genetically homogeneous population of the European anchovy, Engraulis encrasicolus. Fish. Res., 42(3): 229243. doi: 10.1016/S0165-7836(99)00052-1. TURAN, C., D. ERGÜDEN, M. GÜRLEK, N. BAŞUSTA
\& F. TURAN. 2004. Morphometric structuring of the anchovy (Engraulis encrasicolus L.) in the Black, Aegean and Northeastern Mediterranean Seas. Turk. J. Vet. Anim. Sci., 28(5): 865-871.

VERGARA-SOLANA, F.J., F.J. GARCÍA-RODRÍGUEZ \& J. DE LA CRUZ-AGÜERO. 2013. Comparing body and otolith shape for stock discrimination of Pacific sardine, Sardinops sagax Jenyns, 1842. J. Appl. Ichthyol., 29(6): 12411246. doi: 10.1111/jai.12300.

VINAS, J., N. SANZ, L. PENARRUBIA, R.M. ARAGUAS, J.L. GARCÍA-MARÍN, M.I. ROLDÁN \& C. PLA. 2014. Genetic population structure of European anchovy in the Mediterranean Sea and the Northeast Atlantic Ocean using sequence analysis of the mitochondrial DNA control region. ICES J. Mar. Sci., 71(2): 391-397. doi: 10.1093/icesjms/fst132.

WHITEHEAD, P.J.P. 1985. FAO species catalogue. Clupeoids fishes of the world. An annotated and illustrated catalogue of the herrings, sardines, pilchards, sprats, anchovies and wolfherrings. Part 1 - Chirocentridae, Clupeidae and Pristigasteridae. FAO Fisheries Synopsis, 125: 1-303.

WICKHAM, H. 2016. ggplot2: Elegant Graphics for Data Analysis. Springer-Verlag New York. ISBN 978-3-319-24277-4, https://ggplot2. tidyverse.org.

ZENGIN, M., S. SAYGIN \& N. POLAT. 2015. Otolith shape analyses and dimensions of the anchovy Engraulis encrasicolus L. in the Black and Marmara Seas. Sains Malays., 44(5): 657-662.

Received: 22 September 2021

Accepted: 26 October 2021 


\title{
Morfometrija tijela i analiza oblika otolita inćuna (Engraulis encrasicolus (Linnaeus, 1758)) u alžirskom bazenu
}

\author{
Khadra FERHANI*, Djamel BEKRATTOU i Salim MOUFFOK
}

*Kontakt e-pošta:k.ferhani@cnrdpa.dz

\begin{abstract}
SAŽETAK
Morfometrijske karakteristike tijela i oblik otolita opisane eliptičkim Fourierovim deskriptorima analize su provedene na uzorcima europskog inćuna (Engraulis encrasicolus) prikupljenim sa šest lokacija u alžirskim vodama tijekom akustičkog istraživanja ALPEL2018 (jugozapadno Sredozemno more, GFCM-GSA04). Diskriminantna analiza primijenjena je na dvanaest morfometrijskih udaljenosti tijela i 31 normalizirani eliptički Fourier deskriptor. Naglašena je značajna razlika između područja, ali s velikim preklapanjem. Nije otkrivena značajna razlika između mužjaka i ženki, odnosno desnog i lijevog otolita. Provedena hijerarhijska klasterska analiza srednjeg oblika tijela i oblika otolita pokazala je jasnu geografsku klinu. Rezultati pokazuju da je geografski trend prisutan s visokom razinom preklapanja između obližnjih područja, što navodi da europski inćuni u alžirskim vodama nisu potpuno izolirani.
\end{abstract}

Ključne riječi: Morfometrijske karakteristike; oblik otolita; inćun; Alžir 
